\title{
BANYAK YEAST YANG TERKANDUNG PADA PROSES FERMENTASI MOLASSES: DAMPAKNYA TERHADAP KUANTITAS ETHANOL YANG DIHASILKAN DI PT INDO ACIDATAMA KARANGANYAR
}

\author{
Dian Farkhatus Solikha' ${ }^{1)}$, Fathin Firyal Abir ${ }^{2)}$ \\ ${ }^{1)}$ Akademi Minyak dan Gas Balongan,Indramayu, farkhatussolikhadian@gmail.com \\ ${ }^{2)}$ Akademi Minyak dan Gas Balongan, Indramayu, iyalfathin20@gmail.com
}

Diterima 16 Januari 2020, disetujui 18 April 2020, diterbitkan 30 April 2020

Pengutipan: Solikha, D.F \& Abir, F.F. (2020). Banyak Yeast Yang Terkandung Pada Proses Fermentasi Molasses: Dampaknya Terhadap Kuantitas Ethanol Yang Dihasilkan Di Pt Indo Acidatama Karanganyar. Gema Wiralodra, Vol 11, No 1, Hal 107-123, April 2020

\begin{abstract}
ABSTRAK
Fermentasi merupakan proses yang memanfaatkan kemampuan mikroba untuk menghasilkan metabolit primer dan metabolit sekunder dalam suatu lingkungan yang dikendalikan Mikroba itu mengunakan Saccharomyces cereviceae.Tujuan penelitian ini yaitu mengetahui proses pembuatan ethanol dari Molasess, mengetahui pengaruh banyak yeast yang terhadap kuantitas ethanol yang dihasilkan, dan faktor-faktor yang mempengaruhi pertumbuhan yeast pada proses pembuatan ethanol. Metode yang digunakan yaitu metode eksperimen. Berdasarkan hasil penelitian maka dapat disimpulkan bahwa Proses pembuatan ethanol dari Molasess pada plant alkohol di PT. Indo Acidatama Tbk mencakup tiga proses yaitu Seed Fermenteryang Seed Fermentor, Pre Fermentor dan Main Fermentor. Tanki Seed Fermentor terdiri atas tiga tanki, yaitu tanki dengan kode 209 A,B dan C. Tanki Pre Fermentor terdiri atas tanki dengan kode FB 210, 211 dan 212. Sedangkan untuk tanki Main Fermenter memiliki enam tanki dengan tiga tanki berkapasitas $750 \mathrm{~m}^{3}$ (tanki dengan kode FB 213, 214 dan 215), sedangkan tiga tanki lainnya memiliki kapasitas $1000 \mathrm{~m}^{3}$ (tanki dengan kode FB 216, 217 dan 218). Selain itu pengaruh banyak yeast yang terkandung pada proses fermentasi molasses berbanding lurus dengan kuantitas ethanol yang dihasilkan. Maka dapat disimpulkan bahwa apabila jumlah yeast yang terkandung $(\mathrm{Cell} / \mathrm{ml})$ memiliki jumlah yang tinggi maka persentase alkohol yang dihasilkan semakin tinggi. Sedangkan terbentuknya yeast sangat dipengaruhi faktor pendukung yaitu faktor eksternal berupa suhu ruang inkubasi saat fermentasi sedang berlangsung, $\mathrm{pH}$ air campuran, untuk faktor internal berupa campuran dari Urea dan asam fosfat.
\end{abstract}

Kata kunci : ethanol, fermentasi, kadar alkohol, molasses,

\begin{abstract}
Fermentation is a process that utilizes the ability of microbes to produce primary metabolites and secondary metabolites in an environment that is controlled by microbes using Saccharomyces cereviceae. The purpose of this study is to find out the process of making ethanol from Molasess, determine the effect of many yeast on the quantity of ethanol produced, and the factors that influence the growth of yeast in the process of making ethanol. The method used is the experimental method. Based on the results of the study it can be concluded that the process of making ethanol from Molasess in an alcohol plant at PT. Indo Acidatama Tbk covers three processes namely Seed Fermenter which is Seed Fermenter, Pre Fermenter and Main Fermenter. The Seed Fermenter tank consists of three tanks, namely tank with code 209 A, B and C. Pre Fermenter tank consists of tank with code FB 210, 211 and 212. Whereas for Main Fermenter tank has six tanks with three $750 \mathrm{~m}^{3}$ tanks (tank with FB codes 213, 214 and 215), while the other three tanks have a capacity of $1000 \mathrm{~m}^{3}$ (tanks with codes FB 216, 217 and 218). In
\end{abstract}


addition, the influence of many yeasts contained in the molasses fermentation process is directly proportional to the quantity of ethanol produced. It can be concluded that if the amount of yeast contained (Cell / $\mathrm{ml}$ ) has a high amount, the percentage of alcohol produced will be higher. While the formation of yeast is strongly influenced by supporting factors, namely external factors such as incubation room temperature when fermentation is taking place, the $\mathrm{pH}$ of the mixed water, for internal factors in the form of a mixture of urea and phosphoric acid.

Keywords: ethanol, fermentation, alcohol content, molasses,

\section{PENDAHULUAN}

Fermentasi adalah proses yang dilakukan microba atau jasad renik, dimana dengan proses fermentasi dapat mengubah bahan yang mengandung gula seperti sari buah, tetes, dll menjadi alkohol $\left(\mathrm{C}_{2} \mathrm{H}_{5} \mathrm{OH}\right)$. (Masturi, 2017). Produksi alkohol dari biomassa, telah dilakukan orang sekurang-kurangnya sudah 2.000 tahun. Adanya kendaraaan mobil dalam skala komersial pada akhir abad yang lampau, alkohol digunakan pula sebagai bahan bakar. Setelah banyaknya ditemukan sumber bahan bakar minyak, maka pengunaan alkohol menjadi berkurang. Meningkatnya harga bahan bakar minyak, maka alkohol menjadi penting lagi. Pada PT. Indo Acidatama Tbk, Kemiri, Kebakkramat, Karanganyar yang mulai beroperasi tahun 1989 dengan peralatan yang serba modern dan canggih sehingga mampu mengolah tetes tebu sebagai hasil samping pabrik gula menjadi produk-produk kimia yang mempunyai nilai ekonomi tinggi. Produk utama yang dihasilkan di PT. Indo Acidatama Tbk, Kemiri, Kebakkramat, Karanganyar antara lain Ethanol.. Pada proses fermentasi yang dilaksanakan di PT. Indo Acidatama menggunakan bahan baku tetes tebu/Molassedengan Brix serta kadar gula tertentu.

Ethanol atau yang disebut juga etil alkohol $\left(\mathrm{C}_{2} \mathrm{H}_{5} \mathrm{OH}\right)$ yang diproduksi oleh PT Indo Acidatama merupakan bio-ethanol dari tetes tebu (molases) yang difermentasikan oleh yeast dari Saccharomyces cereviseae. Tetes tebu (molases) merupakan cairan kental berwarna cokelat kehitaman yang merupakan buangan akhir proses pengolahan gula setelah mengalami proses kristalisasi berulang. Pada produksi yeast, beberapa subtrat dapat digunakan. Subtrat ini meliputi n-alkana, methanol, ethanol, minyak diesel, limbah industri bir, pati,molasses.Yeast yang diproduksi adalah Candida, Hansenula, Rhodotorula dan Torulopsis.

Beberapa penelitian telah dilakukan mengenai pembuatan bioethanol diantaranya yaitu (1) penelitian oleh Jayus dkk (2016) produksi etanol tertinggi 
ketika digunakan Saccharomyces cereviseae, (2) penelitian oleh Wardani (2013) menyatakan bahwa salah satu faktor yang mempengaruhi produksi etanol adalah penanmbahan Saccharomyces cereviseae, (3) penelitian oleh Agustina (2016) menyatakan bahwa salah satu faktor yang mempengaruhi produksi etanol adalah waktu fermentasi, (4) penelitian oleh Anggraini dkk (2017) menyatakan bahwa salah satu faktor yang mempengaruhi produksi etanol adalah $\mathrm{pH},(5)$ penelitian oleh Kusmiati (2010) menyatakan bahwa salah satu faktor yang mempengaruhi produksi etanol adalah substrat nutrisi, dan sedangkan penelitian oleh (6) Ari (2016) menyatakan bahwa terdapat tiga faktor yang mempengaruhi produksi etanol yaitu waktu fermentasi, penambahan urea, dan penambahan saccharomyces cereviceae. Perlu dilakukan penelitian tentangpengaruh banyak yeast yang terhadap kuantitas ethanol yang dihasilkan, dan faktor-faktor yang mempengaruhi pertumbuhan yeast pada proses pembuatan ethanol.

Perlu dilakukan penelitian tentang pengaruh banyak yeast yang terhadap kuantitas ethanol yang dihasilkan, dan faktor-faktor yang mempengaruhi pertumbuhan yeast pada proses pembuatan ethanol. Maka tujuan penelitian ini yaitu mengetahui proses pembuatan ethanol dari Molasess, mengetahui pengaruh banyak yeast yang terhadap kuantitas ethanol yang dihasilkan, dan faktor-faktor yang mempengaruhi pertumbuhan yeast pada proses pembuatan ethanol.

Saccharomyces cereviceae merupakan jenis Yeast yang paling umum digunakan pada pembuatan roti atau Pada produksi Saccharomyces cerevisae, digunakan media yang mengandung gula, seperti molases.Media dasar Gula. Khamir ini sangat mudah ditumbuhkan, membutuhkan nutrisi yang sederhana, laju pertumbuhan yang cepat, sangat stabil, dan aman digunakan (food-grade organism). Berdasarkan karakteristik tersebut, S. cereviceae lebih banyak digunakan dalam pembuatan Ethanol dibandingkan penggunaan jenis khamir yang lain. (Nuryoto, 2008).

\section{METODE PENELITIAN}

Metode eksperimen yang dilakukan yaitu dengan cara pengujian sampel yang diambil setiap 4 jam sekali dan diuji pada laboratorium dan mengumpulkan data recordyang berada pada ruang operator. 
Pengujian sampel dibagi menjadi dua tahapan analisis yaitu :

\section{Tahap Penelitian}

Pada tahapan ini menggunakan berbagai macam percobaan, meliputi Membuat Media Yield, Membuat YMP Medium, Inokulasi TT Seed, Inokulasi TT Seed kedalam Media Yield, analisa Brix, perhitungan pH, dan Analisa Alkohol Content.

Adapun prosedur pembentukan yeastakan di jelaskan sebagai berikut :

\section{a. Membuat Media Yield}

1) Menimbang :

0,25 gr d.A.P

0,5 gr urea

\section{2,5 gr Yeast Extract}

\section{2,5 gr Pepton}

Tetes $10 \%$ molases dijadikan $600 \mathrm{ml}$

2) Memasukan semua bahan ke dalam beaker glass $250 \mathrm{ml}$

3) Larutkan dengan aquadest

4) Menyiapkan labu takar $500 \mathrm{ml}$ dan $100 \mathrm{ml}$

5) Memasukkan ke labu leher angsa

6) Menutup dengan silicon plack, dan tutup dengan alumunium foil kemudian diikat dan disterilkan dalam autoclave dengan suhu $120^{\circ} \mathrm{C}$ selama 20 menit pada tekanan $1 \mathrm{~atm}$.

\section{b. Membuat YMP (Yeast Media Pepton)}

1) Menimbang:

Yeast Extract Powder : 0,6 gr/200 ml

Malt Extract Powder : 0,6 gr/200 ml

Pepton $\quad: 0,1 \mathrm{gr} / 200 \mathrm{ml}$

Glukosa $\quad: 2 \mathrm{gr} / 200 \mathrm{ml}$

2) Larutkan dengan aquadest

3) Mencampurkan masing-masing larutan diatas dan menjadikan volumenya menjadi $200 \mathrm{ml}$

4) Memasukkan dalam test tube masing-masing $10 \mathrm{~mL}$, lalu menutup test tube tersebut. 
5) Menyeterilkan dengan autoclave pada suhu $120^{\circ} \mathrm{C}$ selama 20 menit pada tekanan $1 \mathrm{~atm}$.

\section{c. Inokulasi TT Seed}

1) Menyeterilkan ruang inokulasi dengan lampu UV minimal 2 jam.

2) Menyeterilkan inkas dengan lampu UV minimal 2 jam

3) Menyeterilkan tangan dengan detol.

4) Secara aseptis menginokulasikan 1 ose yeast dari stock slant ke dalam media YMP kemudian mencampurkan.

5) Menginkubasikan pada incubator dengan suhu $30^{\circ} \mathrm{C}$ selama 24 jam.

\section{d. Inokulasi TT Seed kedalam Media Yield}

1) Mengambil YMP media yang telah diinkubasi, kemudian masukkan kedalam Media Yield, tetapi sebelumnya pada saat memindahkan panaskan dahulu mulut tabung dengan pembakar spiritus dengan tujuan agar steril.

2) Menutup menggunakan muffle leher angsa dan diberi aquadest kemudian menginkubasi selama 3 hari.

Adapun prosedur pendataan sampel molasse pada setiap unit akan di jelaskan sebagai berikut:

\section{e. Analisa Alkohol Content}

1) Mengambil $250 \mathrm{ml}$ mash dengan labu takar, lalu masukkan ke dalam labu destilasi volume $1000 \mathrm{ml}$ dan membilas labu takar dengan aquadest sebanyak $\pm 125 \mathrm{ml}$.

2) Mendestilasi dan menampung destilat dengan erlenmeyer sampai volume $250 \mathrm{ml}$, dan memindahkan ke labu takar $500 \mathrm{ml}$ dan menjadikan volumenya $500 \mathrm{ml}$ dengan aquadest mengaduk hingga homogen, lalu simpan dalam freezer sampai suhu dibawah $20^{\circ} \mathrm{C}$ lalu aduk lagi.

3) Masukkan ke gelas ukur volume $250 \mathrm{ml}$ dan memasukkan spindle alcohol meter range $0-7 \%$ dan membaca tepat pada suhu $20^{\circ} \mathrm{C}$.

\section{f. Analisa kadar Brix}

1) Mengambil mash dalam fermenter lalu memasukkan mash ke dalam pipa uji yang telah diberi indikator saccharimeter

2) Dalam indikator saccharimeterrate 10-25 untuk melihat kekentalan dari mash. 


\section{g. Analisa kadar pH}

1) Mengambil $250 \mathrm{ml}$ mashdari botol sampel lalu memasukkan ke dalam labu takar, lalu masukkan ke dalam gelas beakeryang telah dibilas aquadest

2) Pengeceken kadar $\mathrm{pH}$ menggunakan $\mathrm{pH}$ meter

\section{Tahap Pengamatan}

Pada tahapan ini melakukan berbagai macam pengamatan, meliputi :

1) Jenis yeast yang digunakan

2) Jumlah yeast yang diinokulasi dalam skala lab dan operasional

3) Kadar molase pada Tanki

4) Jenis nutrien yang digunakan

5) Jumlah kadar nutrien yang digunakan

6) Kadar ethanol yang keluar setiap proses fermentasi

\section{HASIL DAN PEMBAHASAN}

Pada unit fermentasi (area 200) ada beberapa proses dalam pembentukan Ethanol mulai dari fase seed fermenter, pre fermenter, dan main ferementer. Saccharomyces cereviseae digunakan untuk produksi ethanol pada fermentasi di penelitian ini sesuai dengan tinjauan penelitian dari Jayus dkk (2016) yang menyatakan bahwa produksi etanol tertinggi ketika digunakan Saccharomyces cerevisea. Fermentasi di PT INDO ACIDATAMA Tbk. ini dilakukan dengan sistem batch.Dimana dalam satu batch terdiri atas satu seed fermentor, pre fermentor dan main fermentor. Tanki seed fermentor terdiri atas tiga tanki, yaitu tanki 209 A, B dan C. Tanki pre fermentor terdiri atas tanki FB 210, 211 dan 212. Sedangkan untuk tanki main fermentor memiliki enam tanki dengan tiga tanki berkapasitas $750 \mathrm{~m}^{3}$ (tanki FB 213, 214 dan 215), sedangkan tiga tanki lainnya memiliki kapasitas $1000 \mathrm{~m}^{3}$ (tanki FB 216, 217 dan 218).

\section{a. Seed fermentor}

Seed fermentor merupakan tempat starter pertama pembenihan ataupertumbuhan jasad renik dalam skala operasional. Proses dalam seed fermentor terdiri dari Cleaning, Sterilisasi Tanki, pembuatan media, Sterilisasi media, pendinginan media, pembiakan media, dan kondisi operasional selama inkubasi. 


\section{1) Cleaning}

Merupakan proses pencucian tanki seed yang akan dipergunakan untuk membersihkan sisa-sisa yeast dan sisa anti-foam dari proses sebelumnya. Dimana proses cleaningseed fermenter tank dilakukan dengan cara menyemprotkan air kedinding tanki lewat sparger yang dilakukan selama 5 menit, kemudian diberi deterjen dan dibilas kembali dengan air sampai deterjen hilang. Kemudian buka valve steam untuk flashing (menghilangkan kotoran yang menyumbat lubang sparger) selama 1 menit. Kemudian masukan larutan formalin sebagai desenfektan. Pemberian larutan formalin hanya dilakukan untuk cleaning tanki kosong, jika tanki telah melalui proses dan baru saja kosong, maka penyemprotan dengan desinfektan tidak perlu dilakukan lagi, hanya langsung saja melakukan sterilisasi pada tanki yang akan digunakan dengan memakai steam.

2) Sterilisasi Tanki

Sterilisasi tanki dilakukan untuk membunuh kontaminan yang mungkin terdapat dalam tanki fermentor maupun media masuk kedalam tanki.Sterilisasi tanki dilakukan dengan prosedur manhole ditutup rapat, shipon pot diisi air 1/3 bagian (untuk mengeluarkan uap air dari sterilisasi). Kemudian valvesteam dibuka perlahan-lahan 1/4 putaran. Dan valvedrain dan valve sampel cook dibuka sedikit untuk mengeluarkan kondensat. Waktu yang dibutuhkan untuk sterilisasi tanki ini adalah 2 jam dan suhu $99-100^{\circ} \mathrm{C}$.

3) Pembuatan Media

Pembuatan media pada seed fermentor dilakukan bersamaan dengan pengisian (filling) pre fermenter maupun main fermenter. Adapun pembuatan media seed meggunakan eslang hose/pipe yang telah direndam dalam larutan formalin sehigga selalu dalam keadaan steril. Pembuatan media seed fermenter dilakukan oleh dua orang, dengan cara tanki penyimpanan sementara FC 207 (molasess) dan FC 206 (air) akan dipompa dan dialirkan ke tanki seed fermenter melalui valve yang berhubungan dengan hose pipe. Air dan molasess akan tercampur dengan volume molasess yaitu $0,25 \mathrm{~m}^{3}$ dan air $2 \mathrm{~m}^{3}$.

\section{4) Sterilisasi Media}

Media fermentasi berupa campuran molasess dan air juga penting untuk disterilisasi untuk menghilangkan kontaminan dalam media. Dimana sterilisasi ini 
berfungsi agar tidak ada kontaminan bakteri atau jasad renik selain yeast yang digunakan. Sterilisasi media dalam seedfermentor dilakukan dengan menggunakan steam. Media panaskan dengan steam hingga mencapai temperatur $99-100^{\circ} \mathrm{C}$ selama 2 jam. Kemudian matikan steam dan biarkan konstan selama 30 menit

5) Pendinginan Media

Pendinginan media dalam sistem fermentasi diperlukan untuk menjaga agar kondisi fermentasi tetap pada suhu optimal $\left(32-35^{\circ} \mathrm{C}\right)$. Secara alami, suhu ketika fermentasi akan terus naik karena aktivitas fermentasi itu sendiri. Pada tanki seed fermentor, sistem pendinginan yang digunakan adalah dengan menggunakan jacket cooler. Cara menggunakan dan membuka aliran pada jacket cooler dilakukan dengan membuka valvecooling water.Waktu untuk mendinginkan tanki adalah sekitar 2-3 jam hingga temperatur tanki menunjukkan angka $31-32^{\circ} \mathrm{C}$. Kemudian menambahkan nutrien berupa urea cair sebanyak 2 liter, asam fosfat 3 liter dan antifoam (Polypropylene glycol) sebanyak 1 liter. Antifoam berfungsi untuk menghilangkan buih yang mana menghambat proses pengembangbiakan yeast.

6) Pembiakan Media dalam Seed Fermenter (Proses Inokulasi)

Sebelum media diberi "yeast" atau ragi maka 2 jam sebelumnya diambil dahulu sampel dari media (mash) untuk dianalisa persentase TS (Total Sugar), kekentalan (Brix) dan juga pH media. Dengan persyaratan kandungan TS awal adalah 10-12\%, Brix awal adalah $16-18^{\circ} \mathrm{BX}$, dan $\mathrm{pH}$ berkisar 5-5,2. Jika persyaratan tersebut sudah terpenuhi, maka inokulasi baru akan dilaksanakan. Proses inokulasi dilakukan dengan cara menyemprot lubang inokulum dengan alkohol 70\% agar steril. Kemudian memasukan inokulum (yeast) dari laboratorium mikrobiologi sebanyak 16 liter (4 labu) melewati lubang inokulum. Selama proses pemasukkan yeastkultur disekeliling lubang inokulum harus selalu disemprot dengan alkohol $70 \%$ agar seteril.

\section{b. Prefermentor}

Tanki pre fermentor merupakan tangki biakan kedua setelah seed fermenter yang digunakan untuk mengembang-biakkan yeast yang akan digunakan dalam main fermentor. Alkohol yang terbentuk pada prefermentor masih berkadar 3-6\%. Adapun proses yang terdapat dalam pre fermentor meliputi:

Diterbitkan oleh:

Universitas Wiralodra

Jln. Ir. H. Juanda Km 3 Indramayu, Jawa Barat 


\section{1) Cleaning Tanki}

Proses cleaning pada pre fermenter sama dengan proses cleaning pada seed fermenter yaitu dengan menyemprotkan air kedinding tanki lewat sparger yang dilakukan selama 5 menit, kemudian diberi deterjen dan dibilas kembali dengan air sampai deterjen hilang. Kemudian buka valvesteam untuk flashing (menghilangkan kotoran yang menyumbat lubang sparger) selama 1 menit. Kemudian masukan larutan formalin sebagai desenfektan.

Pemberian larutan formalin hanya dilakukan untuk cleaning tanki kosong, jika tanki telah melalui proses dan baru saja kosong, maka penyemprotan dengan desinfektan tidak perlu dilakukan lagi, hanya langsung saja melakukan sterilisasi pada tanki yang akan digunakan dengan memakai steam.

\section{2) Sterilisasi Tanki}

Proses sterilisasi tanki sama dengan proses sterilisasi pada seed fermenter yaitu dengan menggunakan steam. Valve steam dibuka perlahan-lahan 1/4 putaran. Tanki di sterilisasi sampai temperatur $99-100^{\circ} \mathrm{C}$, mengguakan surface area jika sudah tercapai, tutup valve steam.Sterilisasi dilakukan selama 1 jam.Jika sudah 1 jam, buka valve aerasi $1 / 2$ putaran untuk mengeluarkan sisa-sisa steam melalui pipa drain agar kondensat terbuang.

3) Pembuatan Media Prefermentor

Pada proses pembuatan media di pre fermenter ini, sebelum molasess dan air masuk, valve filling pre fermenter dibuka dan valve distribusi ke main fermenter tank harus ditutup. Kemudian menuangkan urea $50 \mathrm{~kg}$ dan larutan asam fosfat sebanyak $35 \mathrm{~kg}$, dan menuangkan antifoam (Polypropylene glycol) sebanyak $5 \mathrm{~L}$. Molasess masuk tanki sebanyak $7 \mathrm{~m}^{3}$, dilihat dari flowmeter dan air proses masuk tanki $37 \mathrm{~m}^{3}$.

4) Pasteurisasi Media Pre fermentor

Dilakukan dengan menggunakn steam melalui sparger yang ada di dasar tanki sehingga media akan kontak langsung dengan steam. Pasteurisasi tersebut dilakukan dengan membuka valve steam perlahan-lahan hingga 2,5 putaran. Media yang dipasteurisasi dipanaskan hingga temperatur mencapai $70-80^{\circ} \mathrm{C}$. Dan dilakukan selama 2-3 jam, dan lalu biarkan konstan selama 30 menit. Pasteurisasi 
dihentikan dengan cara menutup valve steam, kemudian baru valve aerasi ditutup. Media tetap dibiarkan dalam kondisi panas untuk mengurangi kontaminan.

5) Pendinginan Media Pre fermentor

Pendinginan media pre-fermenter dilakukan dengan sistem surface area (pertukaran panas antara air dingin dengan dinding tanki), yang mana dilakukan dengan cara memuka valve aerasi $100 \mathrm{~m}^{3} / \mathrm{jam}$ dan buka valvecooling water dengan bukaan penuh. Pendinginan dilakukan hingga suhu tercapai $\pm 32^{\circ} \mathrm{C}$

\section{c. Main fermenter}

Main fermenter merupakan tanki dimana proses perubahan molasesmenjadi ethanol dilakukan hingga kadarethanol mencapai 10-12\%. Tanki main fermenter merupakan tanki yang paling besar di unit Fermentasi (area 200)dan harus dipastikan bebeas dari kontaminan seperti Acetobacter aceti,Lactobacter aceti dan Leuconosto mosenteriodes. Sehingga pada tahapan main fermenter ini dilakukan langkcah-langkah sebagai berikut:

\section{1) Cleaning Tanki Main Fermenter}

Pembersihan (cleaning) pada tanki main fermenter dilakukan dengan 2 cara, yaitu dengan penyemprotan dengan selang lewat manhole dan dengan sprayer yang ada di atas tanki. Dimana tahap/cara dalam melakukan cleaning tersebut adalah:

- Pasang selang pada valve cleaning dan masukkan ke tanki main fermenter lewat manhole, buka valvedrain

- Nyalakan pompa sumersible

- Nyalakan P 203, selang secara manual disemprotkan ke dasar tanki sehingga lumpur (sludge) di dasar tanki bersih, waktu yang diperlukan pada tahap ini 20 menit

- Tutup valve cleaning yang menghubungkan selang dan buka valvecleaning yang menuju sprayer

- Buka valve steam $1 / 2$ putaran

- Dengan P 203 tetap hidup, nyalakan pompa sirkulasi agar pompa sirkulasi dan Heat exchanger dapat bersih, sirkulasi diulang 2-3 kali

- Setelah 40 menit, cleaning dihentikan. Pompa P203, pompa sumersible di hentikan juga dan valve cleaning serta drain ditutup. 
- Jika tanki dalam keadaan kosong tuang formalin 0,5 L dan bilas lagi dengan air.

2) Pembuatan Media Pre fermentor

Pembuatan media dilakukan dengan memasukkan Molasses sebesar 228,75 $\mathrm{m}^{3}$ dan Air $525 \mathrm{~m}^{3}$, Setelah media siap maka proses Filling siap dilakukan.

3) Penambahan Nutrien

Feed dari prefermenter akan dialirkan menuju main fermenter, pada tahap ini merupakan bagian utama dari fermentasi dimana yeast tidak lagi diberi nutrisi melaikan hanya diberi media, dikarenakan pada tahap ini yeast mulai dipekerjakan atau digunakan untuk mengurai molasis atau tetes tebu menjadi alkohol dengan kadar presentase alkohol 8\%-12\% yang kemudian akan diolah kembali di Area 300 atau Unit Destilasi utntuk menaikkan kadar alkohol atau ethanol sesuai kebutuhan pasar.

Urea $\quad:-\mathrm{kg}$

Asam Fosfat : $34 \mathrm{~kg}$

Pada tahap dalam unit Main fermenter penambahan urea tidak lagi digunakan karena pada tahap ini yeast sudah tidak dikembang biakan lagi melainkan digunakan untuk mengurai molasses atau tetes tebu agar menjadi alkohol.

4) Filling Main Fermenter

Selama filling (pengisian media maupun yeast) tetap dilakukan aerasi selama 2 jam agar yeast dapat beradaptasi dari keadaan aerob (perkembangbiakan) menjadi anaerob (pembentukan ethanol). Filling dilakukan dengan mbuka valve filling untuk main fermenter dan buka valve P 203, kemudian mengisi air proses. Setelah air proses ditambahkan selama 10 menit, nyalakan pompa P 107 untuk pengisian molasess. Menyalakan pompa sirkulasi dan $\mathrm{HE}$, buka valvecoolong water inlet dan outlet HE. Ketika filling sudah memasuki menit ke 20, dilakukan transfer yeastmash dari tanki pre fermentor dengan cara gravitasi (dengan membuka valvedrain pre fermentor dan buka valve untuk transfer di main fermentor). Waktu transfer tersebut akan berlangsung selama 15-20 menit. Ketika filling berjalan 1,5 jam, tambahkan urea $100 \mathrm{~kg}$, tanpa penambahan asam fosfat. Pada proses filling waktu yang dibutuhkan sekitar 15-17 jam. Selama filling suhu dijaga pada kisaran $32-35^{\circ} \mathrm{C}$, dengan pendinginan dari Plate and Frame Heat exchanger. Setelah filling berjalan Diterbitkan oleh: Universitas Wiralodra

Jln. Ir. H. Juanda Km 3 Indramayu, Jawa Barat 
4 jam, tanki fermenter diberi antifoam sebanyak $10 \mathrm{~L}$ dan gas $\mathrm{CO}_{2}$ akan dihisap dan dialirkan ke $\mathrm{CO}_{2}$ Plant.

Berikut ini adalah hal-hal yang harus diperhatikan pada saat proses fermentasi:

- Proses fermentasi dapat berjalan dengan baik jika suhu optimum $<35^{\circ} \mathrm{C}$, karena jika melebihi batas suhu tersebut yeast akan mati dan mengakibatkan kadar alkohol dalam mash masih rendah (tidak mencapai 8-10\%). Untuk mengatasi kenaikan suhu dalam tanki main fermentor digunakanlah pengaturan valve cooling dari HE

- Setiap 4 jam diambil sampel untuk di analisa ${ }^{\circ} \mathrm{Bx}$ dan $\mathrm{pH}$

- Pada saat start maupun finish fermentasi juga diambil sampel untuk dianalisa ${ }^{\circ} \mathrm{Bx}$, TS dan kadar alkohol.

- Waktu proses fermentasi berlangsung selama 36-40 jam

- 4 jam sebelum di distilasi diambil sampel untuk dianalisa kadar alkoholnya.

Berdasarkan proses fermentasi tersebut didapatkan data tabel perbandingan dari setiap batch. denganbanyaknya yeast (total Cell) akan mempengaruhi kadar alkohol yang terbentuk :

Tabel 1 Hasil Pengamatan Pengaruh jumlah yeast

\begin{tabular}{|c|c|c|c|c|c|}
\hline No & Tangki & $\begin{array}{c}\text { JumlahYeast } \\
\text { (batch 1) }\end{array}$ & $\begin{array}{c}\text { Range/hargasat. } \\
(\text { Cell } / \mathrm{ml})\end{array}$ & $\begin{array}{c}\text { Jumlah yeast } \\
\text { (batch 2) }\end{array}$ & $\begin{array}{l}\text { Range/hargasat. } \\
\text { (Cell/ml) }\end{array}$ \\
\hline 1. & $\begin{array}{l}\text { Seed } \\
\text { Fermenter }\end{array}$ & $\begin{array}{l}\text { Start } \\
\text { Finish } \\
\text { Alk }\end{array}$ & $\begin{array}{l}0,40 \times 10^{7} \\
4,35 \times 10^{8} \\
2,7 \%\end{array}$ & $\begin{array}{l}\text { Start } \\
\text { Finish } \\
\text { Alk }\end{array}$ & $\begin{array}{l}0,65 \times 10^{7} \\
3,10 \times 10^{8} \\
2,0 \%\end{array}$ \\
\hline 2. & Pre Fermenter & $\begin{array}{l}\text { Start } \\
\text { Finish } \\
\text { Alk }\end{array}$ & $\begin{array}{l}0,40 \times 10^{7} \\
4,60 \times 10^{8} \\
5,3 \%\end{array}$ & $\begin{array}{l}\text { Start } \\
\text { Finish } \\
\text { Alk }\end{array}$ & $\begin{array}{l}0,70 \times 10^{7} \\
4,80 \times 10^{8} \\
5,0 \%\end{array}$ \\
\hline 3. & $\begin{array}{l}\text { Main } \\
\text { Fermenter }\end{array}$ & $\begin{array}{l}\text { Start } \\
\text { Finish } \\
\text { Alk }\end{array}$ & $\begin{array}{l}2,20 \times 10^{8} \\
1,80 \times 10^{8} \\
11 \%\end{array}$ & $\begin{array}{l}\text { Start } \\
\text { Finish } \\
\text { Alk }\end{array}$ & $\begin{array}{l}2,60 \times 10^{8} \\
1,9 \times 10^{8} \\
9,4 \%\end{array}$ \\
\hline \multicolumn{3}{|c|}{ Alkohol yang dihasilkan } & $11 \%$ & & $9,4 \%$ \\
\hline
\end{tabular}




\section{Pembahasan}

Pada tabel tersebut dapat dilihat yeast (Cell/ml)mengalami kenalikan sigifikan dalam setiap parameter. Mulai dari seed fermenter, dan pre fermenter hal ini disebabkan karena dalam proses tersebut inkubasi dalam tangki berjenis aerobatau memerlukan oksigen. Sedangkan pada main fermenterjumlah cell yang terbentuk meningkat tetapi tidak terlalu signifikan. Hal ini terjadi karena proses ingkubasinya berjenis anaerob atau tidak memerlukan oksigen. Dan dari tabel tersebut dapat dilihat pula, parameter ingkubasi awal dan akhir terhadap banyaknya yeastmempengaruhi terbentuk alkohol tersebut.

Terlihat pada batch 1 proses pada tangki Seed Fermenter memiliki jumlah total cell yeast berjumlah 4,35 x 107 dan menghasilkan alkohol 2,7\% sedangkan pada batch 2 memiliki total cellyeast 3,10 x 107 dan menghasilkan alkohol 2,0\%. Lalu pada tangki Pre Fermenter memiliki jumlah total cell yeast berjumlah 4,60 x 107 dan menghasilkan alkohol 5,3\% sedangkan pada batch 2 memiliki total cell yeast 4,80 x 107 dan menghasilkan alkohol 5,0\%. Dan pada tangki Main Fermenter memiliki jumlah total cell yeast berjumlah 1,80 x 108 dan menghasilkan alkohol $11 \%$ sedangkan pada batch 2 memiliki total cell yeast 1,9 x 108 dan menghasilkan alkohol 9,4\%. Dapat disimpulkan bahwa pada tangki seed fermenter dan tangki Pre fermenter berbanding lurus jumlah total cell yeast dengan Alkohol yang terbentuk. Namun, berbeda dengan tangki Main Fermenter.

Namun terdapat penyimpangan jumlah total cell pada tangki main fermenterdengan jumlah alkohol yang terbentuk. Berdasaran penelitian yang telah dilakukan oleh para peneliti sebelumnya terdapat faktor yang mempengaruhi terbentuknya ethanol yaitu penelitian oleh Wardani (2013) menyatakan bahwa salah satu faktor yang mempengaruhi produksi etanol adalah penanmbahan Saccharomyces cereviseae. Agustina (2016) menyatakan bahwa salah satu faktor yang mempengaruhi produksi etanol adalah waktu fermentasi, sedangkan Anggraini dkk (2017) menyatakan bahwa salah satu faktor yang mempengaruhi produksi etanol adalah pH. Kusmiati (2010) menyatakan bahwa salah satu faktor yang mempengaruhi produksi etanol adalah substrat nutrisi dan sedangkan Ari (2016) menyatakan bahwa terdapat tiga faktor yang mempengaruhi produksi etanol 
yaitu waktu fermentasi, penambahan urea, dan penambahan saccharomyces cereviceae.

Berdasarkan penelitian yang dilakukan oleh penulis maka terbentuknya yeast pun sangat dipengaruhi beberapa faktor pendukung internal dan eksternal. faktor eksternal berupa suhu ruang inkubasi saat fermentasi sedang berlangsung, $\mathrm{pH}$ air campuran yang terlalu asam atau terlalu basa maka Saccharomyses cerevisiae tidak akan bisa berkembang dengan sempurna seperti yang diharapkan, untuk faktor internal berupa campuran dari Urea dan asam fosfat. Urea berfungsi sebagai sumber makanan dari Saccharomyses cerevisiae, sedangkan Asam fosfat berfungsi sebagai penguat dari dinding sel Saccharomyses. Maka komparasi antara penelitian sebelumnya oleh para peneliti sebelumnya dengan penelitian yang dilakukan penulis maka faktor yang mempengaruhi pembentukan ethanol yaitu $\mathrm{pH}$, substrat dan suhu.

\section{KESIMPULAN}

Berdasarkan hasil pengamatan dan pengambilan data pada penelitian ini maka dapat disimpulkan yaitu Proses pembuatan ethanol dari Molasess pada plant alkohol di PT. Indo Acidatama Tbk mencakup tiga proses yaitu Seed Fermenteryang Seed Fermentor, Pre Fermentor dan Main Fermentor. Tanki Seed Fermentor terdiri atas tiga tanki, yaitu tanki dengan kode 209 A,B dan C. Tanki Pre Fermentor terdiri atas tanki dengan kode FB 210, 211 dan 212. Sedangkan untuk tanki Main Fermenter memiliki enam tanki dengan tiga tanki berkapasitas $750 \mathrm{~m}^{3}$ (tanki dengan kode FB 213, 214 dan 215), sedangkan tiga tanki lainnya memiliki kapasitas $1000 \mathrm{~m}^{3}$ (tanki dengan kode FB 216, 217 dan 218).

Pengaruh banyak yeast yang terkandung pada proses fermentasi molasse terhadap kuantitas ethanol yang dihasilkan dapat disimpulkan bahwa apabila jumlah yeast yang terkandung (Cell/ml) memiliki jumlah yang tinggi maka persentase alkohol yang dihasilkan akan semakin tinggi. Proses fermentasi pada unit 200 dapat disimpulkan bahwa apabila jumlah Yeast (Cell/ml) ternyata mempengaruhi jumlah ethanol yang terbentuk pada prosesnya. Namun terdapat penyimpangan jumlah total cell pada tangki main fermenterdengan jumlah alkohol yang terbentuk. Terbentuknya yeast pun sangat dipengaruhi beberapa faktor 
pendukung internal dan eksternal. faktor eksternal berupa suhu ruang inkubasi saat fermentasi sedang berlangsung, $\mathrm{pH}$ air campuran yang terlalu asam atau terlalu basa maka Saccharomyses cerevisiae tidak akan bisa berkembang dengan sempurna seperti yang diharapkan, untuk faktor internal berupa campuran dari Urea dan asam fosfat. Urea berfungsi sebagai sumber makanan dari Saccharomyses cerevisiae, sedangkan Asam fosfat berfungsi sebagai penguat dari dinding sel Saccharomyses

\section{DAFTAR PUSTAKA}

Adini, S., Kusdiyantini, E., \& Budiharjo, A. (2015). Produksi Bioetanol dari Rumput Laut dan Limbah Agar Gracilaria sp. dengan Metode Sakarifikasi yang Berbeda. Jurnal Biologi Indonesia, Vol. 16, No. 2.

Agustina, R., Ratman., \& Said, I. (2016). Pengaruh Waktu Fermentasi Terhadap Kadar Bioetanol dari Kulit Jagung Manis. Jurnal Akademika Kimia, Vol.5 No.4, 2016.

Ahmad, R.Z. (2005). Pemanfaatan Khamir Saccharomyces Cerevisiae untuk Ternak. Wartazoa, Vol.15, No.1, 49-55

Anggraini, Abrina., Yuningsih, Sussy., \& Mauritsius. (2016). Pengaruh pH Terhadap Kualitas Produk Etanol dari Molases Melalui Proses Fermentasi. Reka Buana: Jurnal Ilmiah Teknik Sipil dan Teknik Kimia, Vol 2, No 2., 98 105 ,

Arifwan., Erwin., dan Kartika, R. 2016. Pembuatan Bioetanol Dari Singkong Karet (Manihot Glaziovii Muell) dengan Hidrolisis Enzimatik dan Difermentasi Menggunakan Saccharomyces Cerevisiae. Jurnal Atomik, Vol 1, No 1.

Baharuddin, M ., Sappewali., Karisma., \& Fitriyani, J. (2016). Produksi Bioetanol Dari Jerami Padi (Oryza sativa L.) dan Kulit Pohon Dao (Dracontamelon) Melalui Proses Sakarifikasi dan Fermentasi Serentak (SFS). Chimica et Natura Acta ,Vol.4, No.1.

Belitz, H. D., Grosch, W., Schieberle, P. (2009). Food Chemistry. Edisi 4 Revisi. Berlin: springer

Bušić, A., Marđetko, N., Kundas, S., Morzak, G., Belskaya, H., Ivančić Šantek, M., ... \& Šantek, B. (2018). Bioethanol production from renewable raw materials and its separation and purification: A review. Food technology and biotechnology, 56(3), 289-311. Fardiaz, S. 1992. Mikrobiologi Pangan I. Jakarta: Gramedia Pustaka Utama

Febriyanti, A.E., Sari , C.N., dan Adisyahputra. 2016. Efektivitas Media Pertumbuhan Khamir Komersial (Saccharomyces Cerevisiae) untuk

Diterbitkan oleh:

Universitas Wiralodra

Jln. Ir. H. Juanda Km 3 Indramayu, Jawa Barat 
Fermentasi Bioetanol dari Eceng Gondok (Eichhornia Crassipes). Jurnal Biologi Indonesia 12 (2).

Fessenden, R.J. and Fessenden, J.S., (1982). Kimia Organik. diterjemahkan oleh Pudjaatmakan, A. H., Edisi Ketiga, Jilid 1, 237-239. Jakarta : Erlangga

Hanif, M., Mahlia, T.M.I., Aditiya, H.B., \& Abu Bakar, M.S. (2017). Energy and environmental assessments of bioethanol production from Sri Kanji 1 cassava in Malaysia. Biofuel Research Journal, Vol 13, 537-544.

Hart, H. (1987). Organic Chemistry a Short Lecture. New York : McGraw-Hill

Jay, Jayus., N.V,Iga., \& Nurhayati. (2016). Produksi Bioetanol oleh Saccaromyces Cerevisiae FNCC 3210 pada Media Molases dengan Kecepatan Agitasi dan Aerasi yang Berbeda. Jurnal Agroteknologi Vol.10 No. 022016.

Juwita, R. (2009). Studi Produksi Alkohol Dari Tetes Tebu. Makasar: Universitas Hasanudin.

Kusmiati, Thantowi,A., \& Nuswantara, S. (2010). Efek Sumber Karbon Berbeda terhadap Produksi á-Glukan oleh Saccharomyces Cerevisiae pada Fermentor Air Lift. Jurnal Natur Indonesia 13 (2) Februari 2011.

Kustyawati, M.E., Sari, M., \& Haryati, T. (2013). Efek Fermentasi dengan Saccharomyces Cerevisiae Terhadap Karakteristik Biokimia Tapioka. Jurnal Agritech Vol. 33 No. 3.

Leta. (2009). Penerapan Bioteknologi dalam Ekstraksi Minyak Kelapa dengan Menggunakan Khamir Roti (Saccharomyces Cerevisiae). Jurnal Matematika, Sains, dan Teknologi Vol.10 No.2.

Manurung, E.W., Bustan, D., \& Royen, H. (2013). Pembuatan Etanol dari Tepung Ubi Kayu dengan Menggunakan Metode Hidrolisa. Vol.19 No.3 Jurnal Teknik Kimia.

Masturi., Cristina, A ., Istiana,A ., Sunarno., \& Dwijananti, P. (2017). Ethanol Production from Fermentation of Arum Manis Mango Seeds (Mangifera Indica L.) using Saccharomyces cerevisiae. Jurnal Bahan Alam Terbarukan 6 (1).

Murniati ., Handayani, S.S ., dan Risfianty, D.K. 2018. Bioetanol dari Limbah Biji Durian (Durio Zibethinus). J. Pijar MIPA Vol. 13 No.2.

Nuryoto. (2008). Studi Kinerja Katalisator Lewatit Monoplus s-100 pada Reaksi Esterifikasi antara Etanol dan Asam Asetat . Vol. 2, No. 1. Cilegon: Universitas Sultan Ageng Tirtayasa .

Polli, F.F. (2016). Penelitian Pembuatan Etanol dari Serat/Ampas Sagu. Jurnal Penelitian Teknologi Industri Vol. 8 No. 1.

Riadi, L. (2007). Teknologi Fermentasi Cetakan Pertama. Jogjakarta: Graha Ilmu Diterbitkan oleh:

Universitas Wiralodra

Jln. Ir. H. Juanda Km 3 Indramayu, Jawa Barat 
Rizal, S., \& Kustyawati, M.E. (2019). Karakteristik Organoleptik dan Kandungan Beta-Glukan Tempe Kedelai Dengan Penambahan Saccharomyces Cerevisiae. Jurnal Teknologi Pertanian, Vol. 20 No. 2.

Reis,V.R., Bassi, A.P.G., Gomes, J.C, \& Ceccato, S.R. (2013). Characteristics of Saccharomyces cerevisiae Yeasts Exhibiting Rough Colonies and Pseudohyphal Morphology with Respect to Alcoholic Fermentation. Brazilian Journal of Microbiology, Vol 44, No 4.

Rizwan, M., Diah, A.W.M.. \& Ratman. (2018). Pengaruh Konsentrasi Ragi Tape (Saccharomyces Cerevisiae) Terhadap Kadar Bioetanol Pada Proses Fermentasi Biji Alpukat (Persea Americana Mill). Jurnal Akademika Kimia Vol 7, No 4.

Ruslina Y. D. M. (2012). Laporan Kerja Praktek pada Unit Fermentasi Pt. Indo Achidatama. Depok : Universitas Indonesia.

Rustiaty, B. (2018). Optimalisasi Sel Saccharomyces Cerevisiae untuk Meningkatkan produktivitas dan Efisiensi Industri Etanol. Jurnal Teknologi \& Industri Hasil Pertanian, Vol. 23, No.2.

Susmiati, Y. (2018). Prospek Produksi Bioetanol dari Limbah Pertanian dan Sampah Organik the Prospect of Bioethanol Production from Agricultural Waste and Organic Waste. Jurnal Teknologi dan Manajemen Agroindustri Vol.7, No.2.

Sofiah ., Yuniar., \& Rani, D.A. (2019). Pembuatan Bioetanol dari Umbi Singkong Karet (Manihot Glaziovii) yang Dihodrolisis Asam dan Enzim. Prosiding Seminar Nasional II Hasil Litbangyasa Industri ISSN 2654-8550.

Utami, L.I. (2009). Pembuatan Etanol Dari Buah Mengkudu. Jurnal Teknik Kimia, Vol.4, No.1.

Wachid, M \& Mutia, P. (2019). Optimasi Media Kulit Singkong pada Pertumbuhan Sacharomyces Cerreviceae. Jurnal Ilmiah Teknik Sipil dan Teknik Kimia, Vol 4 , No 2.

Widyanti, E.M \& Moehadi, B.I. (2016). Proses Pembuatan Etanol dari Gula Menggunakan Saccharomyces Cerevisiae Amobil. Jurnal Metana, Vol. 12, No 2.

Wusnah., Bahri, S., dan Hartono, D. (2016). Proses Pembuatan Bioetanol dari Kulit Pisang Kepok (Musa acuminata B.C) Secara Fermentasi. Jurnal Teknologi Kimia Unimal, Vol 5, No 1. 